Article

\title{
Christmas Allowance as a Non-System Tool for Sustainability of Quality of Life of Slovak Seniors
}

\author{
Jarmila Vidová ${ }^{1, *(\mathbb{D})}$ and Peter Sika ${ }^{2}$ (I) \\ 1 Department of Economic Policy, Faculty of National Economy, University of Economics, 85104 Bratislava, \\ Slovak Republic \\ 2 Department of Social Development and Labour, Faculty of National Economy, University of Economics, \\ 85104 Bratislava, Slovak Republic; peter.sika@euba.sk \\ * Correspondence: jarmila.vidova@euba.sk; Tel.: +421-2-6729-1420
}

Received: 16 March 2020; Accepted: 2 May 2020; Published: 7 May 2020

\begin{abstract}
Creating conditions for a sustainable level of quality of life for older people is considered the dominant priority when setting up the pension system with an emphasis on the income situation of Slovak seniors for old-age pensions. An old-age pension as a systemic benefit is an important element in maintaining the quality of life of older people. The amount of old-age pensions is currently at the center of discussions between institutions and the Government of the Slovak Republic. A major social but also economic problem in the coming decade will be how to maintain the income of older people, pensioners, needed to ensure their sustainable quality of life. In particular, it is necessary to ensure that pensioners receive sufficient income so that they do not become a population at risk of poverty as the groups at risk of poverty or social exclusion also includes people over the age of 65. The paper focuses on the analysis of the socio-economic situation of Slovak pensioners in the Slovak Republic in connection with material deprivation. At the same time we analyze the Christmas contribution as a non-systemic benefit which, on the one hand, has a positive social impact on the recipients of pension benefits who are entitled to the Christmas benefit but, on the other hand, has a negative impact on the general government budget.
\end{abstract}

Keywords: Christmas allowance; poverty; solidarity; sustainability; welfare state; quality of life

\section{Introduction}

Research on quality of life in recent years is extensive in many countries, proving that it has a place in the social sciences [1-3]. It includes economic, social, and above all living conditions, as well as material security, political freedom, independence, and social justice [4-12]. Pigou (1924), as one of the first scientists in the context of discussions on economics and social well-being, mentioned the term "quality of life" [4]. Most of the quality of life research has been conducted in the United States and focused on exploring satisfaction, happiness, and well-being. The theoretical model of quality of life as "good life" was created by Lawton [5]. Holková's research into quality of life was based on the theory of consumption. Among other things it focused on examining the relationship of savings and spending over the life cycle with a view to maintaining an adequate standard of living during retirement [1]. The increase in the number of older people is an urgent problem in today's society, as it also entails increased costs for the health system and social security. Politicians in the Slovak Republic also target retirement households as potential voters and are therefore willing to support non-systemic measures. The Government of the Slovak Republic has already taken this path in 2006 and in its program statement it has committed itself to provide Slovak seniors with a Christmas contribution differentiated according to their pension according to the financial possibilities of the state budget. Already in 2006, the Government of the Slovak Republic undertook in its Program Statement to provide 
Slovak seniors with a Christmas allowance differentiated according to the amount of their pension and according to the financial possibilities of the state budget. The aim of the government was to improve the social situation of recipients of old-age and disability pensions. Our goal is to analyze in detail the legislative and technical process of paying the Christmas allowance in the Slovak social system and at the same time to point out its non-systematic nature.

\section{Theoretical Background}

The high rates of economic growth, the development of new technologies, and the growth of industrial production have led to quality of life becoming associated with the negative impacts of economic development on the environment. The issue of quality of life gradually came into the environment as a broadly conceived approach, oriented not only toward the state of the environment but also on the overall state of society. In this way, critics of unlimited economic growth have expressed concern about the future conditions for human life. In the 1960s, the Rome Club linked the issue of quality of life to the global problems of a deteriorating environment. Galbraith [13], in the context of increasing consumption, used the term quality of life in response to mass consumption. Rostow [14] examined the phases of economic growth and assumed that after a massive mass consumption stage, society would move to the search for a new quality of life, but this was not fulfilled.

In the 1960s and 1970s, the concept of quality of life also began to be used in sociology to highlight the need to seek new ways of assessing quality of life by using indicators that take into account the social context and assess not only objective but also subjective perceptions of one's own quality of individual life [15]. At that time, sociology introduced the concept of social indicators describing the objective conditions of life of society.

Psychology has been gradually introduced into the study of quality of life. Psychology is interested in the overall subjective evaluation of life from a position of an individual, analyzing factors influencing their subjective feeling. It monitors the quality of life through cognitive and emotional dimensions. The cognitive dimension consists of conscious and rational evaluation of life while the emotional dimension affects emotional experience. Thus, quality of life began to be monitored in the context of well-being, which is a subjective approach to quality of life, i.e., subjective evaluation. Discussions on quality of life have been conducted both in the UK and in the US where the first research was conducted. Scientists focused mainly on the content and definition of this term. Many contradictory opinions and concepts have emerged. Most of them were futuristic, focused on models of future perspectives of way of life. The trend of the 1970s and 1980s became the so-called post-materialism, which emphasized the value of quality of life, where priority was given to civil liberties, personality development, leisure time development, and tourism.

In the 1990s, research into quality of life further expanded with a view to a thorough definition of the theoretical foundations of quality of life and the development of indicators that would allow quantifying the quality of life in its complexity. Discussions on defining the importance of quality of life in the context of sustainable development have been renewed. The basis of this theory is quality of life is determined primarily by the highest number of possible ways of satisfying the individual's desires, achieving maximum yield and usefulness [16]. Laluha understands quality of life as a socio-economic category that is tied to the satisfaction of needs, and quality of life depends on the height, nature, and structure of the needs being met [17]. According to Lehman, quality of life is a subjective factor manifested by a feeling of well-being depending on personal characteristics (age and sex), objective indicators (e.g., level of financial income), and subjective indicators (e.g., satisfaction with financial income) [18]. An important part of quality of life is from an economic point of view: the standard of living which is measured by means of significant economic indicators such as income, expenditure, consumption, and household equipment. Income comes from economic activity during an active working life. In retired families, these are savings, but especially old-age pensions. In addressing the quality of life of Slovak pensioners, we focused on the phenomenon of standard of living defined in by the Economic Encyclopedia [19] as "the degree of satisfaction of people's life needs and a summary of 
conditions arising from social relationships in which these needs are satisfied". Standard of living is used as an analytical tool to monitor the living conditions of the population to study its socio-economic status and to measure the satisfaction of life needs. It is necessary to realize that the practical assurance of quality of life is a social and political problem and, therefore, the low level of pension benefits is subsidized by the Government of the Slovak Republic, mainly from the means of general taxation in the form of a Christmas allowance to pensions. It follows that quality of life does not have a uniform definition and research focuses on several areas of life, housing conditions, living needs, environmental conditions, and rest and recreation conditions, as well as social comfort. The quality of research into retirement age is an important area. Assessing the quality of life of older people is increasingly important not only because of the increasing number of older adults but also because of the increase in life expectancy and technological advances in medicine [20].

We are of the opinion that the standard of living plays an important role in assessing the quality of life, as well as the practical assurance of the quality of life is above all a social and political problem. Standard of living was used from the outset as an analytical tool for monitoring the living conditions of the population. The indicators of the living standard describe basic aspects of poverty and social exclusion and allowed the main risk areas and their impact on poverty and social exclusion to be identified, which we will discuss in the next section.

The cost of retirement households, covering their living needs as well as the cost of state social security systems, are increasing. In the next part of the research we focused on the quality of life of retired households in the context of retirement incomes. Adequacy of pensions is closely linked to the well-being of people and the social sustainability of the pension system [21].

\section{Socio-Economic Situation of Slovak Pensioners' Households}

Solidarity can be defined as the voluntary renunciation of part of one's own surplus or advantage in favor of one who is deficient or disadvantaged [22,23].

According to Keller [24], the functioning of society would not have been possible without some degree of solidarity; the author even argues that solidarity is a prerequisite for the very existence of society. Solidarity between different population groups (especially between the rich and the poor) is a manifestation of the social model applied in each country. At present, help through charitable organizations is not enough but the solidarity of the rich and the poor must also be reflected in the social model as one of the foundations of the construction of society. The welfare state is a unique phenomenon in each country as it reflects certain specific historical, cultural, economic, political, and other conditions. The welfare state has grown up as a means of economic and political stabilization and job creation. As the Danish social theorist G. Esping-Andersen [25] writes, it is not possible to imagine a welfare state that does not, in one way or another, distribute income and resources. Today, however, it is highly costly and confronted with changes such as aging and is, therefore, under pressure to be rebuilt. The welfare state in Slovakia has profiled itself as a system orientated by its social policy primarily to dampen social impacts on the living conditions of people and to fulfill the protective function. In building its system, Slovakia followed the Bismarck system and built social protection mainly on the insurance model.

The welfare state in Slovakia has become a frequently used and debated term in recent years, especially in connection with the direction of reforms, also the left-wing of governmental power which sought at least partial decomodification by strengthening solidarity and introducing various social benefits where we clearly include the Christmas contribution. The welfare state is not only a professional but political term, too.

The welfare state focuses on social policy areas aimed at responding to the social risks of a citizen (e.g., old age) or to the possible negative consequences a citizen faces (e.g., disability). At the same time, its aim is to eliminate the social consequences that may result in the poverty of vulnerable groups [26]. 
The concept of social exclusion is closely linked to the concept of poverty. Both of these concepts are closely related yet, even if they partially overlap, they are not identical phenomena. They differ in the causes and individual dimensions, as well as how they are manifested [27].

The problem of poverty and social exclusion has not been the focus of EU member states for quite a long time. It was not until the 1970s and 1980s that, in times of economic crisis, joint, coordinated action on combating poverty appeared. The European Commission (EC) considers poor people to be families and groups of people whose material, cultural, and social resources are so limited that they exclude them from the minimum accepted standard of living of the member state in which they live. In the Slovak Republic, the term "poverty" was defined in the National Action Plan of Social Inclusion 2004-2006 of the Slovak Republic and was based on the approach of the European Commission [28].

The share of people at risk of poverty or social exclusion in the Slovak Republic decreased from 2005 to 2009 (from $32.0 \%$ to $19.6 \%$ ). The economic crisis saw a slight increase (to $20.6 \%$ in 2010 and 2011). Since 2012, indicators in Slovakia have been improving. Since 2014, the trend of decreasing the percentage of people at risk of poverty or social exclusion has continued. In 2017, $16.3 \%$ of the population in Slovakia was at risk of poverty or social exclusion, which is below the EU average $(22.5 \%)[29,30]$.

Since 2008, 255,000 people have been lifted out of poverty or social exclusion, thus fulfilling Slovakia's Europe 2020 target to reduce the number of people at risk by at least 170,000 by 2020 (Figure 1). However, there are population groups that are more at risk, not only in Slovakia but in other EU countries, as well. These are mainly children from socially disadvantaged backgrounds and the Roma minority. Children were three times more at risk of poverty compared to those aged 65 and over. Groups at risk of poverty or social exclusion also include single-parent families, people with disabilities, and homeless people. In general, the proportion of people at risk of poverty is gradually decreasing with increasing age. This is mainly due to the setting up of the social protection system and expenditure, e.g., social transfers, including old-age and survivors' pension benefits. The impact of social transfers, including old-age and survivors' pension benefits, on reducing poverty risk was up to $66.5 \%$ [30].

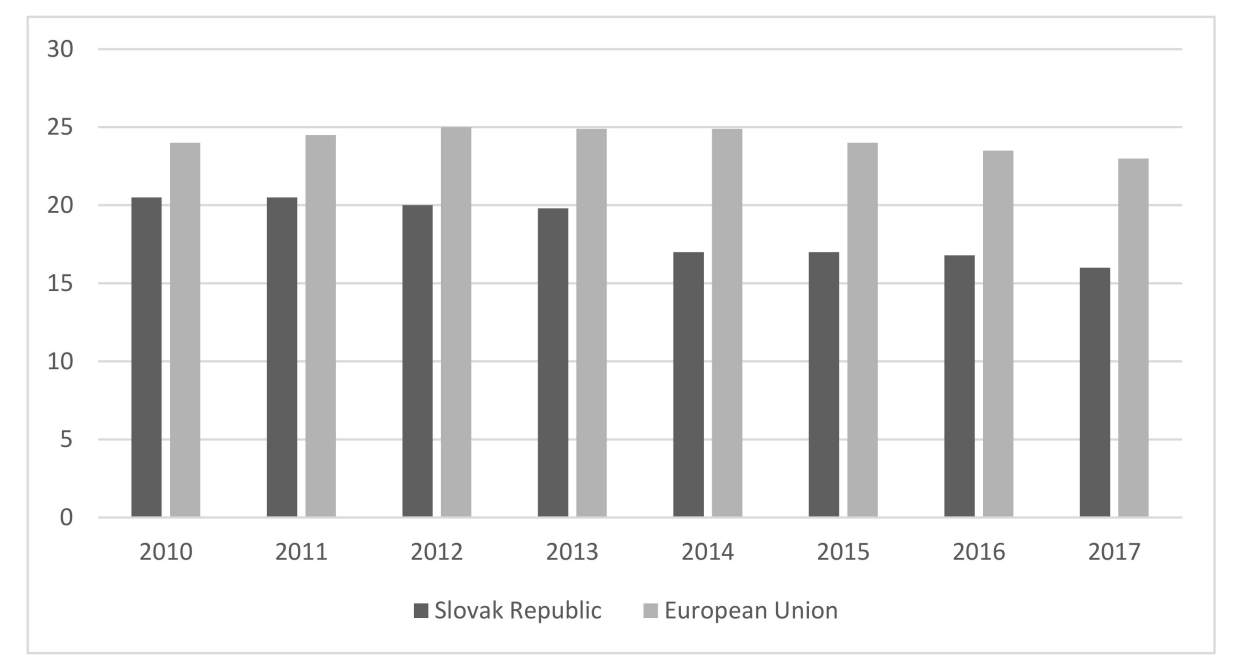

Figure 1. The degree of risk of poverty or social exclusion Slovak Republic and EU (\%). Source: Created by authors on date [30-32].

The amount of old-age retirement pensions is lower than incomes from individuals' economically active period. The decrease in incomes of households of pensioners decreases the possibility of meeting the needs of pensioners' households, which is also negatively influenced by the growth of consumer prices, which in June 2019 increased by 2.6\% in total compared to 2018.

The Government of the Slovak Republic also responds to this fact with the valorization of pension benefits. For 2018 to 2021, a minimum rate of valorization of pension benefits was introduced. 
Pensioners increase their pension benefits by the percentage of the year-on-year growth in consumer prices of pensioners' households, at least by a fixed amount determined as $2 \%$ of the average amount of the respective type of pension. Starting in January 2020, approximately $88 \%$ of seniors will valorize their pension benefit for pension inflation, which is $2.9 \%$. The remaining pensioners will increase their pension by a fixed amount corresponding to $2 \%$ of the average amount of the pension in question, which is $€ 9$ for 2020 .

Thanks to this measure, below-average retirement pension benefits will grow faster and may dampen the decline in the income of pensioners' households as up to $6.9 \%$ of people aged 65 and over live at risk of poverty (Figure 2).

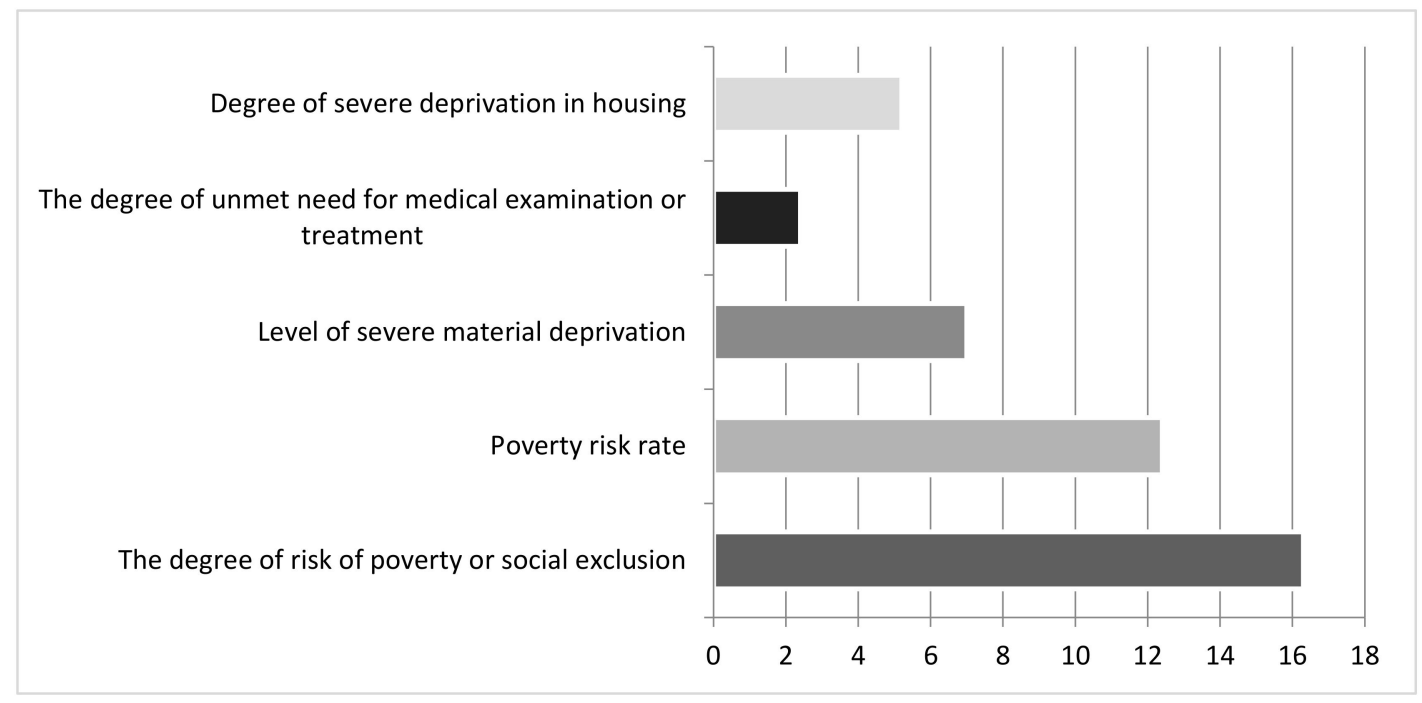

Figure 2. Social exclusion indicators, 2017 (\% of population). Source: Created by authors on date $[29,30,32,33]$.

The 55-75 years old age group has experienced the greatest increase in incomes over the last 20 years and pensioner poverty has declined very rapidly in many countries, so it is now below the average in the OECD population [33]. Over the past 20 years, average old-age pensions in Slovakia have been in the order of 43 to 48 percent of the average wage in a given year. For comparison, while in 1991 the average old-age pension amounted to $€ 67$, the average gross monthly wage in the economy was $€ 125$. Currently, retirement pension beneficiaries have an average pension of $€ 444$ and an average wage of $€ 1013$ (Figure 3).

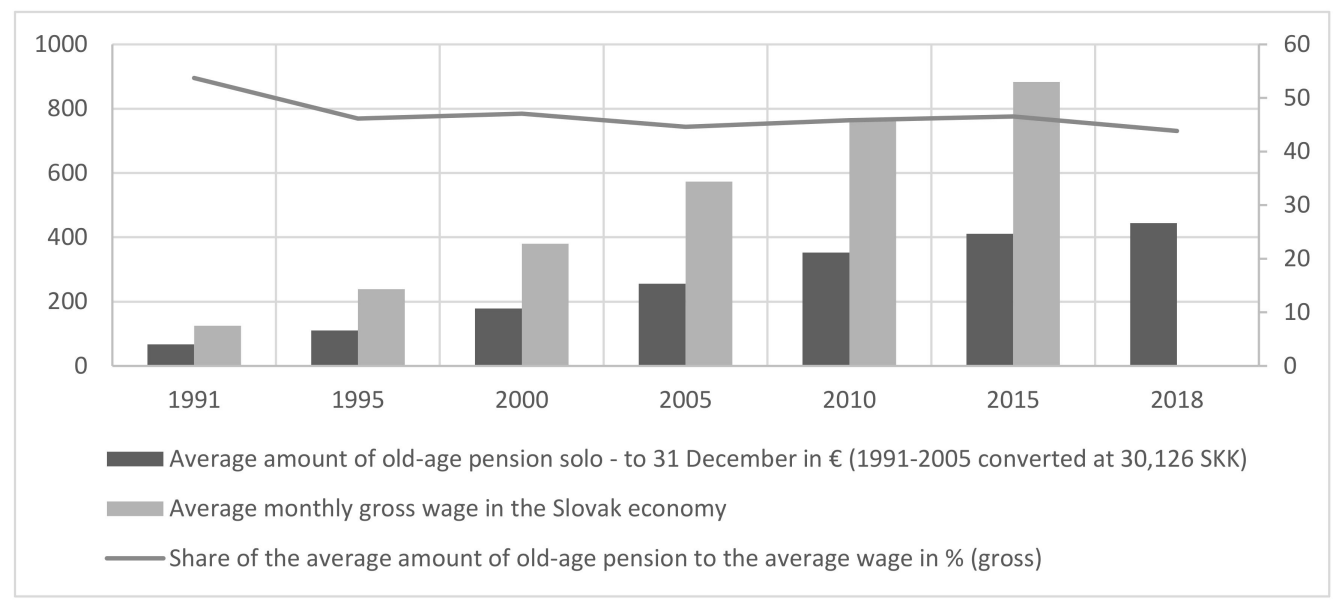

Figure 3. Relation between the average amount of old-age pension solo (as of 31 December) and average monthly wage in the Slovak economy. Source: Created by authors on date [34]. 
Despite the fact that Slovak seniors do not belong among the most vulnerable populations affected by poverty, the Government of the Slovak Republic (Government of the SR, 2006, p. 27) has set one of its goals to raise their standard of living through a Christmas allowance [35]. On the contrary, child poverty has deepened and is currently above average in the general population. The results of a survey in 2016 show that $21.4 \%$ of children aged 0-15 were at risk of poverty and compared to the survey in 2015, the indicator increased by $0.6 \%$. In the case of children 0-17 years, based on the results of the Labor Force Sample Survey, their share in households without employment decreased from $9.3 \%$ to $7.7 \%$. In this age group, according to The European Union Statistics on Income and Living Conditions (EU-SILC) 2016 results, the percentage of those who live in households with very low work intensity (occasional work) rose from $8 \%$ to $8.2 \%$. This is despite the clear evidence that the well-being of children is a key determinant of the quality of their adult life-how much they will earn, how healthy they are, and so on. The increase in child poverty deserves more political attention than it currently receives in many countries.

In the following part of the paper, we will discuss the genesis of legislative changes in the Christmas pension as well as its merits. We will also focus on the financial impact of paying Christmas pensions on public finances and, in particular, on the income situation of pension beneficiaries.

\section{Materials and Methods}

Through a theoretical analysis of domestic as well as foreign sources we defined dimensions of quality of life in the context of a fiscal instrument for more than a ten-year observation period. By analyzing the documents, we examined the legislative definition of the Christmas contribution. Furthermore, in the empirical part, we used a secondary analysis on the basis of which we analyzed the data on poverty of selected population groups. By using abstraction, we ignored some of the parts and features of the subject matter in question so as to address only those characteristics that were essential to our focus. We formulated the conclusions by generalizing on the basis of the examined indicators.

\section{The Mechanism for Determining the Amount of the Christmas Allowance}

The legislative conditions for the provision of the Christmas allowance are regulated by Act No. 592/2006 on the provision of a Christmas allowance to certain pension beneficiaries and on the amendment of certain acts, as amended [36]. The Christmas allowance is paid to the recipient of a pension (retirement pension, early retirement pension, disability pension, social pension, widow's pension, widower's pension, orphan's pension, pre-qualified retirement pension, pre-qualified retirement pension, retrained retirement pension, pre-qualified orphan's retirement pension) resident in the territory of the Slovak Republic, provided that the amount of the pension payable in December of a calendar year does not exceed $60 \%$ of the average monthly wage in the economy of the Slovak Republic reported by the Statistical Office of the Slovak Republic for the calendar year preceding.

In order to financially help more people in the Christmas period, which brings with it a higher financial burden, in 2019, the ceiling for entitlement to the Christmas allowance was increased from $60 \%$ to $65 \%$ of the average monthly wage in the Slovak economy reported by the Statistical Office of the Slovak Republic in the calendar year preceding the calendar year in which the Christmas allowance is paid. The average monthly wage in 2018 was $€ 1013$.

In accordance with Article $1 \S 1$ section 8 of Act No. 592/2006 Z. z. amount of Christmas allowance:

(a) is $€ 200$ if the amount of the pension or the total of pensions is no more than the minimum subsistence figure for one adult natural person $[\mathrm{D} \leq \mathrm{ZM}]$ (Notes: $\mathrm{D}$ is the amount of pension income, $\mathrm{ZM}$ is the sum of the subsistence minimum for one adult natural person, $\mathrm{M}$ is the average monthly wage in the economy of the Slovak Republic one year ago, VP is the amount of the Christmas allowance.) (From 1 July 2019, the amount for the first adult natural person is $€ 210.20$, for the second adult natural person is $€ 146.64$, and for a dependent child or dependent minor is €95.96), 
(b) shall be determined according to the formula:

$$
\mathrm{VP}=200-0.36 \times(\mathrm{D}-\mathrm{ZM})
$$

if the amount of the pension or the sum of the pension amounts is greater than the subsistence minimum for one adult natural person and does not exceed twice the subsistence minimum for one adult natural person

$$
[\mathrm{ZM}<\mathrm{D} \leq 2 \times \mathrm{ZM}]
$$

(c) is determined according to the formula:

$$
\mathrm{VP}=\operatorname{Max}\{174.52-0.36 \times(\mathrm{D}-\mathrm{ZM}) ; 10\}
$$

if the amount of the pension or the sum of the amounts of the pensions is more than twice the subsistence minimum for one adult natural person; the amount of the Christmas allowance is at least $€ 10$.

According to the Ministry of Labor, Social Affairs and Family of the Slovak Republic (2019), the total number of persons concerned, including the Christmas allowances paid, was estimated at approximately 1,30 million people in 2019. Compared to 2018, the number of Christmas subscribers was expected to increase by approximately 72,000 people due to an increase in the entitlement to the Christmas subsidy from $€ 572.4$ to $€ 658.5$. Total expenditure on the Christmas allowance was estimated at around 154.3 million euros in 2019.

The Christmas allowance is paid by the pension payer (Social Insurance Agency) or one of the authorities (Military Social Security Office, Customs Directorate of the Slovak Republic, Directorate General of the Prison and Judicial Guard Corps, Directorate General of Railway Police, Ministry of Interior, Slovak Information Service, and National Security Authority) to which the Christmas post belongs. If the pension to which the Christmas allowance is paid is assigned to both the Social Insurance Agency and the Office, the Christmas allowance is paid by the payer of the pension.

According to Article $1 \S 1$ par. 1 of Act No. 592/2006 Coll. as amended, a state social benefit does not belong to a recipient of a pension residing in the territory of one of the states of the European Economic Area and Switzerland except for a citizen of the Slovak Republic. Furthermore, the Christmas allowance does not belong to a recipient of a pension resident in the territory of a contracting state, as no Slovak social security agreement applies to this state social benefit.

In relation to the determination of the condition of residence in the territory of the Slovak Republic, the Slovak Republic faced an action brought by the Commission before the Court of Justice. The Commission based its legal opinion on the Regulation on the Coordination of the Social Security Systems of the Member States of the Union Regulation (EC) No. 883/2004 (Regulation of the European Parliament, 2004), which prohibits, in principle, discrimination on the basis of the criterion of the state of residence [37]. In its judgment on 16 September 2015, the Court ruled that the granting of the Christmas allowance is subject to precise and objective conditions which leave the competent authorities no discretion as to the personal needs of the applicant. The Court also held that, although the purpose of the Christmas allowance is to supplement the means of subsistence of persons who have reached a certain age, it is also intended to improve the difficult social situation of other low-income recipients. In those circumstances, the Court ruled that the Commission had not shown that the Christmas allowance could be classified as an old-age benefit which, as a result, fell within the scope of the regulation and, therefore, dismissed the action (Court of Justice of the European Union, 2015) [38].

\section{Discussion}

Pursuant to the Act No. 592/2006 Coll. on the provision of Christmas allowances to certain pension beneficiaries and on amendments to certain laws, the Ministry of Labor, Social Affairs and Family of 
the Slovak Republic prepared a regulation of the Government of the Slovak Republic stipulating the amount of Christmas allowances for the relevant year [36].

Government Regulation No. 603 of the Slovak Republic of November 2006 stipulated that the amount of the Christmas allowance [39] was differentiated according to the amount of the pension or the sum of the pension amounts as follows: 2,000 SKK (€66.39) if the amount of the pension was up to 3,455 SKK ( $€ 114.69)$; 1,750 SKK ( $€ 58.09$ ) if the amount of the pension or the sum of the pension amounts was from 3,456 SKK ( $€ 114.70)$ to 6,910 SKK ( $€ 229.37)$; and 1,500 SKK (€49.80) if the amount of the pension or the sum of the pension amounts was from 6,911 SKK (€229.38) to 10,365 SKK (€344.06). In 2007, the Ministry of Labor, Social Affairs and Family of the Slovak Republic prepared the Order of the Government of the Slovak Republic No. 489, which set the amount of the Christmas allowance [40] per year for 2007: 2,000 SKK ( $€ 66.39)$ if the amount of the pension or the sum of the pension amounts was up to 3,753 SKK (€124.58); 1,750 SKK (€58.09) if the amount of the pension or the sum of the sums of pensions was from 3,754 SKK ( $€ 124.59)$ to 7,505 SKK ( $€ 249.12)$; and 1,500 SKK ( $€ 49.80)$ if the amount of the pension or the sum of the pension amounts was from 7,506 SKK ( $€ 249.13)$ to 11,257 SKK (€373.66). The average amount of Christmas allowance per recipient was 1,584 SKK (€52.58).

Act No. 463/2008 extended the range of beneficiaries of the Christmas allowance to beneficiaries of solo widow's pension, solo widow's pension, and solo orphan's pension. In accordance with the Act No. 463/2008, the Ministry of Labor, Social Affairs and Family of the Slovak Republic prepared the Government Order of the Slovak Republic laying out the amount of Christmas allowance in 2008 in the amount of 1,500-2,000 SKK ( $€ 49.80-66.39)$, differentiated according to the amount of pension: 2,000 SKK (€66.39) if the amount of the pension or the sum of the pension amounts was up to 4,030 SKK $(€ 133.78) ; 1,750$ SKK ( $€ 58.09)$ if the amount of the pension or the sum of the pension amounts was from 4,031 SKK ( $€ 133.79)$ to 8,059 SKK ( $€ 267.51)$; and 1,500 SKK (€49.80) if the amount of the pension or the sum of the pension amounts was from 8,060 SKK (€267.54) to 12,088 SKK (€401.25). The average amount of Christmas allowance per recipient was 1,623 SKK (€53.87).

In 2009, there were no legislative changes and for this reason the Ministry of Labor, Social Affairs and Family of the Slovak Republic prepared the Order of the Government of the Slovak Republic No. 409, establishing the amount of the Christmas allowance per year 2009: €66.39 if the amount of the pension or the sum of the pension amounts was up to $€ 144.70, € 58.09$ if the amount of the pension or the sum of the pension amounts was $€ 144.80$ to $€ 289.30$, and $€ 49.80$ if the amount of the pension or the sum of the pension amounts was $€ 289.40$ to $€ 433.90$.

In 2010, the Christmas allowance payment mechanism was modified, which was more effective than the Christmas allowance payment mechanism in previous years, as a more efficient escalation of borders and amounts of the Christmas allowance were used, while the new concept took greater account of lower income retirees. The total number of pensioners who received the Christmas allowance in 2010 was 1,131,102 pensioners. In the Regulation of the Government of the Slovak Republic No. 409 of October 2010, the amounts of the Christmas allowance for 2010 were fixed at:

- $€ 66.39$, if the amount of the pension or the sum of the pension amounts was up to $€ 186.20$,

- $€ 62.69$, if the amount of the pension or the sum of the pension amounts was up to $€ 186.30$ to $€ 223.40$,

- $€ 58.95$, if the amount of the pension or the sum of the pension amounts was up to $€ 223.50$ to $€ 260.60$,

- $€ 55.23$, if the amount of the pension or the sum of the pension amounts was up to $€ 260.70$ to $€ 297.80$,

- $€ 51.50$, if the amount of the pension or the sum of the pension amounts was up to $€ 297.90$ to $€ 335.10$,

- $€ 47.78$, if the amount of the pension or the sum of the pension amounts was up to $€ 335.20$ to $€ 372.30$, 
- $€ 44.06$, if the amount of the pension or the sum of the pension amounts was up to $€ 372.40$ to $€ 409.50$, and

- $€ 40.34$, if the amount of the pension or the sum of the pension amounts was up to $€ 409.60$ to $€ 446.70$.

On 1 August 2011, Act No. 242/2011 Coll. fixed the limit of the amount of the pension benefit for the Christmas allowance (60\% of the average monthly wage in the economy of the Slovak Republic) and linked the amounts of the Christmas allowance to the subsistence minimum: $€ 66.39$ if the amount was the sum of the retirement pension beneficiaries' pensions at most in the amount of the subsistence minimum for one adult natural person. However, if the amount of the retirement pension or the sum of the pension recipients' sums was higher than the subsistence minimum for one adult natural person, the amount of the Christmas allowance was calculated according to the formula: VP $=66.39-0.10 \times$ (D - ZM), where: VP is the amount of the Christmas allowance, $D$ is the amount of the pension or the sum of the sums of pensions and $\mathrm{ZM}$ is the amount of the subsistence minimum for one adult natural person (€189.83).

Decree Act No. 293/2012 of the Ministry of Labor, Social Affairs and Family of the Slovak Republic laying out the amount corresponding to $60 \%$ of the average monthly wage in the Slovak economy for the year 2011, which was decisive for the Christmas allowance in 2012, entered into force on 1 September 2012. The amount in question was set at $€ 471.60$. Pensioners with a lower pension or equal to $€ 471.60$ were entitled to a Christmas allowance in 2012.

The amount corresponding to $60 \%$ of the average monthly wage in the Slovak economy for 2012, which was decisive for providing the Christmas allowance in 2013, was a measure of the Ministry of Labor, Social Affairs and Family of the Slovak Republic No. 294/2013 fixed at $€ 483$. Pensioners with a lower pension or equal to $€ 483.00$ were entitled to a Christmas allowance in 2013. The maximum amount of the Christmas grant increased from $€ 66.39$ to $€ 75.00$. The Christmas allowance was calculated according to the formula: VP $=75.00-0.10 \times(\mathrm{D}-\mathrm{ZM})$. (Note: In 2013, the subsistence minimum amount for one adult natural person was $€ 198.09$.)

The year 2014 brought some changes in the payment of the Christmas allowance to pension beneficiaries under Act No. 240/2014 Coll. In particular, the following changes were made:

- the maximum amount of the Christmas allowance increased to $€ 87.26$;

- the coefficient of 0.10 in the Christmas allowance formula was changed to 0.18 , thus achieving increased solidarity with low-income pension recipients;

- pensions were taken into account:

- received from the special system of social security for police and soldiers,

- received from abroad,

- paid out of the old-age pension savings scheme; and

- the amount of the Christmas allowance was increased by $€ 12.74$ for recipients of the Christmas allowance with retirement pensions up to $€ 396.18$ - twice the subsistence minimum for one adult natural person-qualified.

The Christmas allowance in 2014 was arranged created by for pensioners who had a pension equal or lower than $€ 494.40$. The Christmas allowance was calculated in 2014 according to the formula: $\mathrm{VP}=87.26-0.18 \times(\mathrm{D}-\mathrm{ZM})$.

In 2015, the amount of the Christmas allowance increased once again by $€ 12.74$ for recipients of the Christmas allowance with the total amount of retirement pensions up to and including $€ 396.18$. The entitlement to the Christmas allowance in 2015 included pensioners who had a pension less than or equal to $€ 514.80$.

As the subsistence level did not increase in 2016, the individual amounts necessary to calculate the amount of the Christmas allowance did not change. Expenditure for the payment of the Christmas 
allowance to some pension beneficiaries in 2016 (excluding supplements) was 77.4 million euros, while in 2015 it was 77.2 million euros.

In order to improve the status of low-income pensioners, the Act No. 266/2017 Coll. was created. A one-off increase in the amount of the Christmas allowance by $€ 12.74$ was granted in 2017 to those Christmas benefit recipients whose sums of several pensions were up to twice the amount of the subsistence minimum for one adult natural person. The amount of the Christmas allowance was increased by $€ 12.74$ for recipients of the Christmas allowance with the total amount of pensions up to and including €398.96. In December 2018, the Social Insurance Agency paid a Christmas allowance to $1,179,494$ pensioners in the total amount of $€ 74,188,318.09$ (Figure 4). The Christmas allowance was calculated in 2018 according to the formula: VP $=87.26-0.18 \times(\mathrm{D}-\mathrm{ZM})$. (Note: In 2018, the subsistence minimum amount for one adult natural person was $€ 198.09$.) The Christmas allowance was increased by a single $€ 2.74$ if the amount of the pension or the sum of the pension amounts was $€ 410.14$ per month or less.

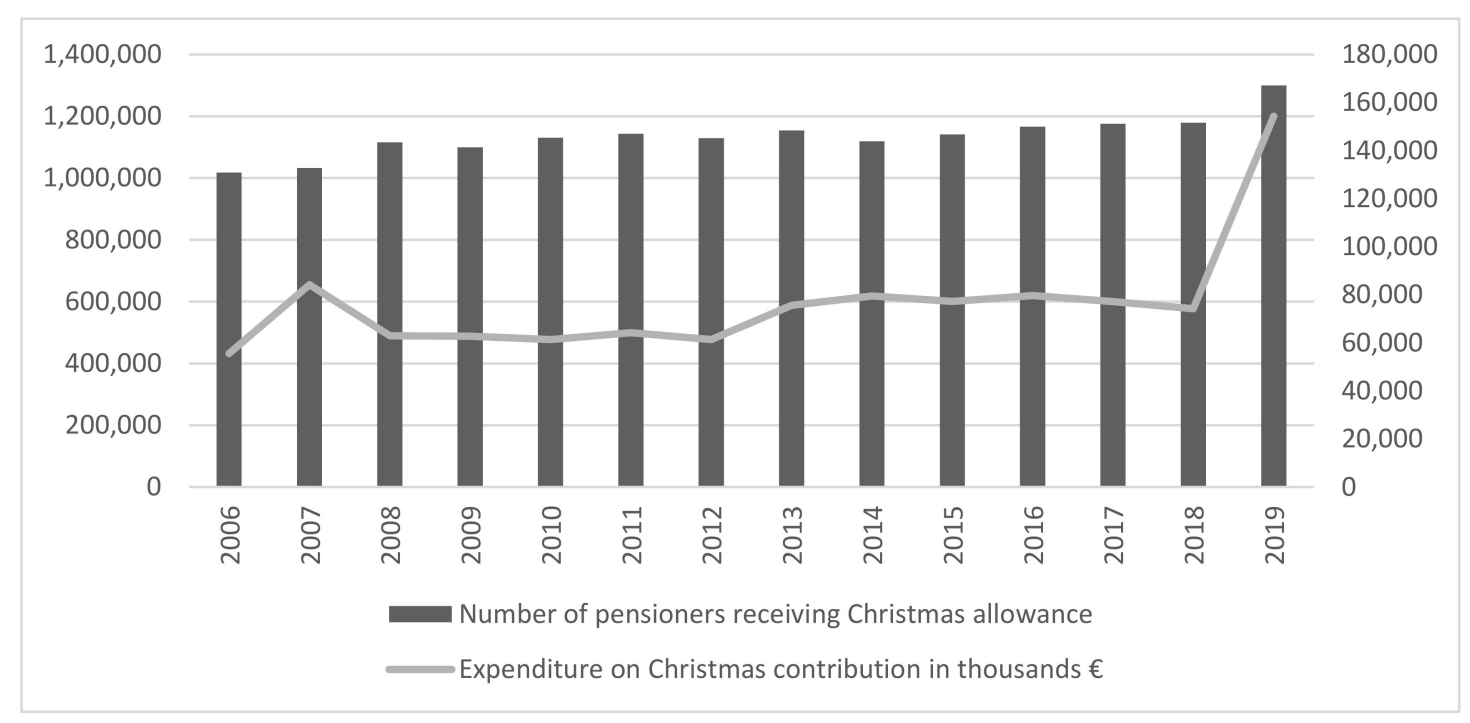

Figure 4. Expenditure on Christmas allowance 2006-2019a . Source: Authors' processing according to data [39-47]. Note: expenditure on Christmas contribution 2019 was assumption of the Ministry of Labor, Social Affairs and Family of the Slovak Republic; a including surcharge for previous years.

Based on the detailed legislative and technical process of the Christmas allowance as a non-systemic benefit in the Slovak social system, we were able to clearly prove that seniors were not the main group at risk of poverty. Furthermore, through the analysis we managed to show that some Slovak politicians say that they are thinking of improving the quality of life of Slovak pensioners through the transformation of so-called Christmas benefit for the 13th pension, but this is not true, as its benefit for the elderly decreases from year to year, as evidenced by the values calculated in Figure 5 . Calculated figures show that Christmas pensions accounted for only $57.89 \%$ of the monthly pension for people with the lowest pension in 2006 and only $14.47 \%$ of the monthly pension for people with pension at the upper limit of the qualifying pension. In 2018, this ratio represented only $42.55 \%$ of the monthly pension for people with the lowest pension level (or $48.76 \%$ with a one-off increase of $€ 12.74)$. For pension beneficiaries at the maximum level, it was only $3.70 \%$, which is clearly not the thirteenth pension. 


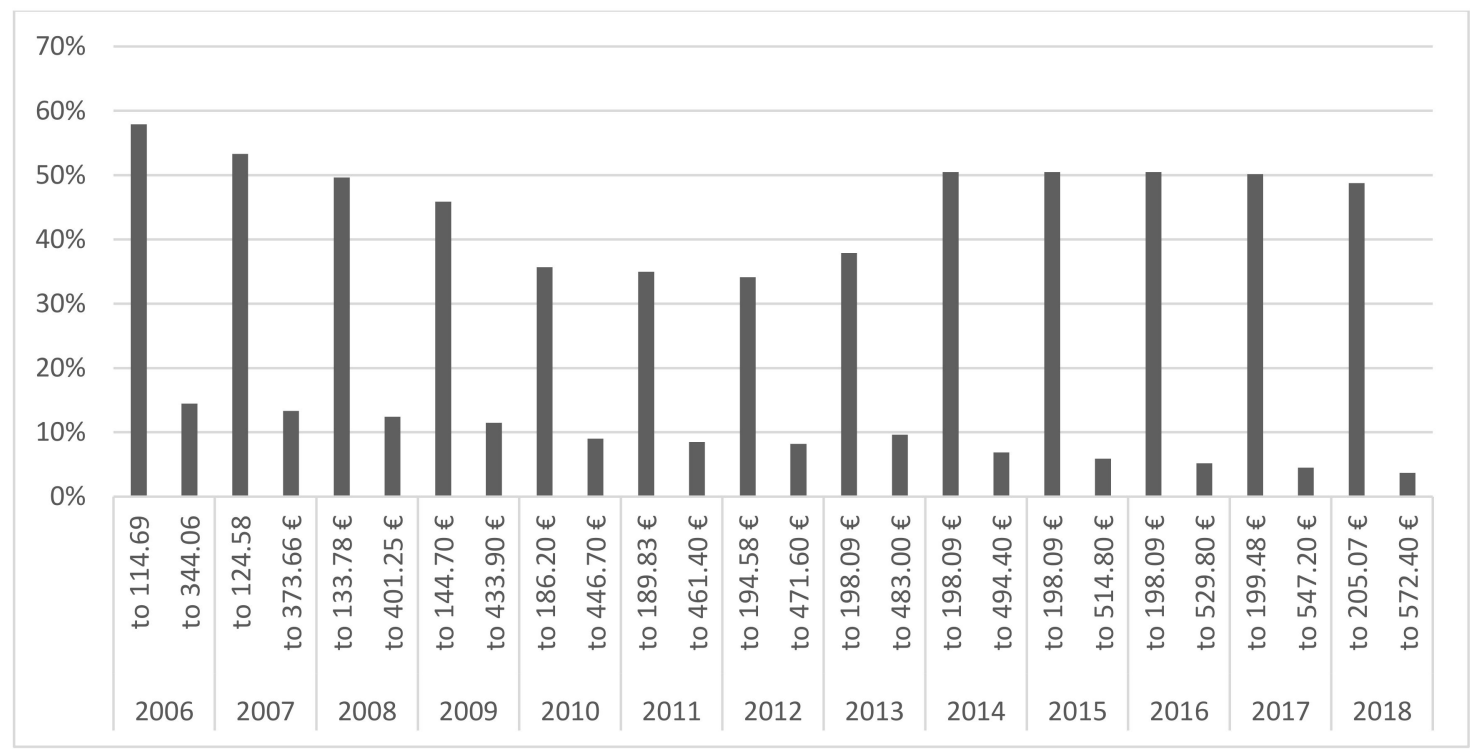

Figure 5. Ratio of Christmas allowance to monthly pension. Source: Authors' own processing.

\section{Conclusions}

In the paper, we discussed the Christmas allowance as a new form of income increase in retirement age, which should serve to maintain an adequate standard of living for Slovak seniors. The Christmas allowance as a non-systemic benefit has a positive social impact on the recipients of pension benefits who qualify for the Christmas benefit, but has a negative impact on the general government budget (Figure 4) and at the same time it is not paid in a sufficiently targeted way since it does not take into account the actual property situation of pensioners but only the amount of the old-age pension. In particular, the government should provide financial support to those groups that are more vulnerable to poverty, especially families with children.

The situation of children in Slovakia is not favorable. This is despite the economic situation in 2018 improving and the number of people at risk of poverty or social exclusion declining. Among the demographic groups, it is children who are most at risk of income poverty in Slovakia. Persistent poverty is twice as high in children up to 18 years as in the general population [48].

The higher risk of child poverty and in particular poverty and deprivation of single-parent households and multi-child households is also related to the lower efficiency of social transfers compared to the EU average. Social transfers reduce the poverty of children under 18 in the EU by 13.3 percentage points on average, in Slovakia only 8.4 percentage points [49].

Despite the fact that the group of pensioners does not belong to the category most at risk of poverty, the Government of the Slovak Republic is gradually considering transforming the Christmas contribution into the so-called 13th pension for recipients of pension benefits. However, the current Christmas allowance cannot be considered the thirteenth pension, since it amounted to only $57.89 \%$ of the monthly pension for people with the lowest pensions in 2006 and only $14.47 \%$ of the monthly pension for people with a pension at the upper limit the pension is still paid. In 2018, this ratio represented only $42.55 \%$ of the monthly pension for people with the lowest pensions (or $48.76 \%$ with a one-off increase of $€ 12.74$ ). For pension beneficiaries at the maximum level, it was only $3.70 \%$, which is clearly not the thirteenth pension (Figure 5). However, it is not yet known whether there would be so-called the thirteenth full pension paid to all pension beneficiaries in future, or if it would depend, for example, on the amount of the subsistence minimum. The first option would have a significant positive impact on the incomes of beneficiaries of all types of pensions, as well as on increasing the rate of replacement of pensions to the average wage, while avoiding discrimination, as it would be granted to all pension beneficiaries. The disadvantage of this alternative is, in particular, a considerable widening of the deficit of the Social Insurance Agency, which is already an issue. At the 
same time, this would be a non-systemic measure, as the provision does not result from the actuarial principle applied in the pension system and at the same time the element of solidarity is disappearing. The second alternative, which is based on solidarity, also shows positive aspects in the form of a positive impact on the incomes of the lowest pensioners, as well as an increase in the replacement rate of this group of pensioners. The negative side of this alternative is the clear dissatisfaction of higher income pensioners, the deepening of the deficit of the Social Insurance Agency, as well as the unclear change in the construction of the subsistence minimum for the future. It should be borne in mind that, according to a survey by the Statistical Office, recipients of pension benefits are not among the most vulnerable groups at risk of poverty. If the Government of the Slovak Republic is interested in systematic assistance to pension benefit recipients, it may proceed with a systematic increase in pensions. However, this measure does not affect the marketing of approximately 1.2 million pensioners who qualify for the Christmas contribution as if the same amount of resources were distributed over a regular monthly pension. If the financial amount allocated to pay the Christmas allowance was divided into a monthly pension benefit, the means would be used to improve the standard of living of pensioners and not to purchase Christmas gifts for their family members.

Defending the merits of the Christmas allowance through the "payout history" is not a sufficient argument for its merits [50]. Quite the contrary, it addresses a political dimension rather than professional. The horizontal dimension clearly points to the need for a systematic increase in pension benefits, which will also ensure an overall improvement in the quality of life of seniors, as Slovak seniors ranked 25th in the Global Retirement Index [51].

Author Contributions: Conceptualization, P.S. and J.V.; methodology, P.S. and J.V.; validation, P.S. and J.V.; formal analysis, P.S. and J.V.; resources, P.S. and J.V.; writing-original draft preparation, P.S. and J.V.; writing-review and editing, P.S. and J.V.; visualization, P.S. and J.V.; funding acquisition, P.S. and J.V. All authors have read and agreed to the published version of the manuscript.

Funding: This research received no external funding.

Acknowledgments: The paper is the output of the research grant VEGA no. 1/0251/19 "Investments of households in housing and the possibility of their alternative use as additional income at the time of receiving the pension benefit".

Conflicts of Interest: The authors declare no conflict of interest.

\section{References}

1. Holková, V.; Laluha, I.; Dudová, I.; Vidová, J.; Vondrová, A.; Psárska, M. Mikroekonomické Súvislosti Spotreby a Kvality Života Domácností SR; Vydavatel'stvo EKONÓM: Bratislava, Slovakia, 2010.

2. Antalová, M. Trh Práce a Sociálna Ekonomika-Špecifické Otázky a Problémy; Vydavatel'stvo EKONÓM: Bratislava, Slovakia, 2018.

3. Veenhoven, R. The Four Quality of Life. Ordering Concepts and Measures of the Good Life. J. Happiness Stud. 2000, 1, 1-39. [CrossRef]

4. Pigou, A.C. The Economics of Welfare, 2nd ed.; Macmillan: London, UK, 1924. [CrossRef]

5. Lawton, M.P. The varieties of wellbeing. Exp. Aging Res. 1983, 9, 65-72. [CrossRef] [PubMed]

6. Oliver, J.; Huxley, P.; Bridges, K.; Mohamad, H. Quality of Life and Mental Health Services; Taylor \& Frances/Routledge: London, UK, 1996.

7. Wood-Dauphinee, S. Assessing quality of life in clinical research: From where have we come and where we are going? J. Epidemiol. 1999, 52, 355-363. [CrossRef]

8. Cabrera-Barona, P.F.; Merschdorf, H. A Conceptual Urban Quality Space-Place Framework: Linking Geo-Information and Quality of Life. Urban Sci. 2018, 2, 73. [CrossRef]

9. Rzońca, E.; Bień, A.; Wdowiak, A.; Szymański, R.; Iwanowicz-Palus, G. Determinants of Quality of Life and Satisfaction with Life in Women with Polycystic Ovary Syndrome. Int. J. Environ. Res. Public Health 2018, 15, 376. [CrossRef] [PubMed]

10. Andrews, F.M.; Withey, S.B. Social Indicators of Well-Being. In Americans Perceptions of Life Quality; Plenum Press: New York, NY, USA, 1976. [CrossRef]

11. Diener, E. Subjective well-being. Psychol. Bull. 1984, 95, 542-575. [CrossRef] [PubMed] 
12. Diener, E. Subjective well-being: The science of happiness, and a proposal for a national index. Am. Psychol. 2000, 55, 34-43. [CrossRef] [PubMed]

13. Galbraith, J.K. Společnost Hojnosti; Svoboda: Praha, Czech Republic, 1967; p. 335.

14. Rostow, W.W. Politic and the stages of Growth; ČSAV: Praha, Czech Republic, 1982.

15. Cummins, R.A.; Gullone, E. Why we should not use 5-point Likert scales: The case for subjective quality of life measurement. In ICQOLC 2000: Proceedings of the Second International Conference on Quality of Life in Cities: 21 Century QOL, 8-10 March 2000, Westin Stamford Hotel, Singapore; National University of Singapore: Singapore, 2000; pp. 74-93.

16. Fahrenberg, J.; Myrtek, M.; Schumacher, J.; Brähler, E. Fragebogen zur Lebenszufriedenheit (FLZ). In Handanweisung; Hogrefe: Goettingen, Germany, 2000.

17. Laluha, I. Kvalita života. In Stanek, V. a Kol: Sociálna Politika; Sprint dva: Bratislava, Slovakia, 2008; p. 135.

18. Ondrejka, I.; Drímalová, M.; Fetisovová, Ž.; Adamicová, K. Koncepcia kvality života a jej význam v zdravotníctve. Slov. Lekár 2001, 11, 25.

19. Economic Encyclopedia; Svoboda: Praha, Czech Republic, 1984.

20. Layte, R.; Fahey, T.; Whelan, C.T. Income Deprivation and Well-Being among Older Irish People; National Council on Ageing and Older People: Dublin, UK, 1999; ISBN 1-900378-13-2.

21. Grech, A.G. What makes pension reforms sustainable? Sustainability 2018, 10, 2891. [CrossRef]

22. Botek, O. Sociálna Politika pre Sociálnych Pracovníkov; PN print: Piešt’any, Slovakia, 2009; p. 112, ISBN 978-80-7357-585-4.

23. Sika, P.; Antalová, M.; Nováková, M.; Pongrácz, E.; Rievajová, E.; Šipikalová, S. Sociálna politika; Vydavatel'stvo EKONÓM: Bratislava, Slovakia, 2018; ISBN 978-80-225-4544-0.

24. Keller, J. Soumrak Sociálního Státu; Sociologické nakladatelstvi: Praha, Czech Republic, 2006.

25. Esping-Andersen, G. (Ed.) Welfare State in Transition; SAGE Publications: London, UK, 1996. [CrossRef]

26. Gerbery, D.; Džambazovič, R. Inovatívne Orientácie v Sociálnej Politike: Perspektíva Sociálnej Inklúzie; Univerzita Komenského v Bratislave: Bratislava, Slovakia, 2011; ISBN 978-80-223-2998-9.

27. Halušková, E.; Božik, J. Chudoba, Spoločenské Súvislosti a Sociálne Politiky na jej Odstránenie; IRIS: Bratislava, Slovakia, 2015; p. 244. ISBN 978-80-8153-040-1.

28. MPSVaR SR. Národný Akčný Plán Sociálnej Inklúzie 2004-2006 SR; MPSVR SR: Bratislava, Slovakia, 2004.

29. Statistical Office of the Slovak Republic, EU SILC (2005-2017). Poverty and Social Exclusion Indicators; Statistical Office of the Slovak Republic: Bratislava, Slovakia, 2018; ISBN 978-80-8121-624-4.

30. MF SR. Review Expenditure on Groups at Risk of Poverty or Social Exclusion; Ministry of Finance of the Slovak Republic: Bratislava, Slovakia, 2019; p. 10. Available online: https:/www.finance.gov.sk/sk/financie/hodnotaza-peniaze/revizia-vydavkov/ohrozene-skupiny/ (accessed on 7 June 2019).

31. EU SILC 2017. Poverty indicators and social exclusion. Available online: www.statistics.sk (accessed on 7 June 2019).

32. Statistical Office of the Slovak Republic. Income, Expenditure of Private Households of the SR in 2018; Statistical Office of the Slovak Republic: Bratislava, Slovakia, 2019; ISBN 978-80-8121-625-1.

33. OECD: Rastúca nerovnost'? Rozdelenie Príjmov a Chudoba v Krajinách OECD. 2008. Available online: https://www.oecd.org/els/soc/41528631.pdf (accessed on 6 June 2019). 
34. Social Insurance Agency. Vzt’ah priemernej výšky vyplácaného starobného sólo dôchodku (31.12.) a priemernej mesačnej mzdy v hospodárstve SR. 2019. Available online: https://www.socpoist.sk/vztah-priemernej-vyskyvyplacaneho-starobneho-solo-dochodku--k-3112--a-priemernej-mesacnej-mzdy-v-hospodarstve-sr/3166s (accessed on 20 February 2020).

35. Program Declaration of the Government of the SR; Government of the SR: Bratislava, Slovakia, 2006; Available online: https://www.vlada.gov.sk/data/files/979_programove-vyhlasenie-vlady-slovenskej-republiky-od04-07-2006-do-08-07-2010.pdf (accessed on 16 June 2019).

36. Zákon, No. 592/2006 Z. z. Poskytovaní Vianočného Príspevku Niektorým Poberatel'om Dôchodku a o Doplnení Niektorých Zákonov v Znení Neskorších Predpisov; National Council of the Slovak Republic: Bratislava, Slovakia, 2006.

37. Nariadenie Európskeho Parlamentu a Rady č. 883/2004 z 29. apríla 2004 o Koordinácii Systémov Sociálneho Zabezpečenia. Available online: https:/eur-lex.europa.eu/legal-content/sk/TXT/?uri=CELEX\% 3A32004R0883 (accessed on 3 April 2019).

38. Súdny dvor Európskej únie Rozsudky vo Veciach C-361/13 a C-433/13. 2015. Available online: http://curia.europa.eu/juris/document/document.jsf;jsessionid=B1090DE633DA462BF50D05F2F5FF1BA0? text=\&docid $=167822 \&$ pageIndex $=0 \&$ doclang $=$ SKK\&mode=lst\&dir $=\& o c c=$ first \&part $=1 \& c i d=3603786$ (accessed on 4 June 2019).

39. MPSVaR SR. Nariadenie Vlády Slovenskej Republiky č. 603/2006 Z. z. 2006. Available online: https: //www.slov-lex.sk/pravne-predpisy/SKK/ZZ/2006/603/20061115.html (accessed on 5 June 2019).

40. MPSVaR SR. Nariadenie Vlády Slovenskej Republiky č. 489/2007 Z. z. 2007. Available online: https: //www.epi.sk/zz/2007-489 (accessed on 5 June 2019).

41. MPSVaR SR. Nariadenie Vlády Slovenskej Republiky č. 413/2008 Z. z. 2008. Available online: https: //www.epi.sk/zz/2008-413 (accessed on 5 June 2019).

42. MPSVaR SR. Nariadenie Vlády Slovenskej Republiky č. 409/2009 Z. z. 2009. Available online: https: //www.epi.sk/zz/2009-409 (accessed on 5 June 2019).

43. MPSVaR SR. Nariadenie Vlády Slovenskej Republiky č. 409/2010 Z. z. 2010. Available online: https: //www.epi.sk/zz/2010-409 (accessed on 5 June 2019).

44. MPSVaR SR. Opatrenie Ministerstva Práce, Sociálnych Vecí a Rodiny Slovenskej Republiky č. 293/2012 Z. z. 2012. Available online: https://www.epi.sk/zz/2012-293 (accessed on 6 June 2019).

45. MPSVaR SR. Opatrenie Ministerstva Práce, Sociálnych Vecí a Rodiny Slovenskej Republiky č. 294/2013 Z. z. 2013. Available online: https://www.epi.sk/zz/2013-186 (accessed on 6 June 2019).

46. MPSVaR SR Úrad Vlády Slovenskej Republiky. 2019. Available online: https://rokovania.gov.sk/RVL/ Material/23677/2 (accessed on 6 June 2019).

47. MPSVaR SR. Aktualizácia Národnej Rámcovej Stratégie Podpory Sociálneho Začlenenia a Boja Proti Chudobe. 2017. Available online: https://www.employment.gov.sk/files/slovensky/rodina-socialna-pomoc/aktualizcianrs.pdf (accessed on 5 January 2020).

48. Kusá, Z. Chudoba detí do 18 Rokov je Dvakrát Vyššia ako vo Zvyšku Populácie. 2018. Available online: https://domov.sme.sk/c/20839584/chudoba-socialny-system-medzinarodny-den-deti.html (accessed on 19 April 2020).

49. Kusá, Z. Tieňová Správa o Chudobe a Sociálnom Vylúčení v Slovenskej Republike. Slovenská Siet' Proti Chudobe; IRIS: Bratislava, Slovakia, 2012; p. 11. ISBN 978-80-971225-53.

50. Hudecová, D. Zmeny v Penziách: Minimálny Dôchodok aj Nová Valorizácia. 2012. Available online: https://uzitocna.pravda.sk/dochodky/clanok/26732-zmeny-v-penziach-minimalny-dochodok-ajnova-valorizacia/ (accessed on 20 April 2020).

51. Global Retirement Security. 2019. Available online: https://www.im.natixis.com/us/resources/globalretirement-index-2019-report (accessed on 20 April 2020).

(C) 2020 by the authors. Licensee MDPI, Basel, Switzerland. This article is an open access article distributed under the terms and conditions of the Creative Commons Attribution (CC BY) license (http://creativecommons.org/licenses/by/4.0/). 